\title{
Clopidogrel resistance "Live" - the risk of stent thrombosis should be evaluated before procedures
}

\author{
Zuzana Motovska*1, Petr Widimsky ${ }^{1}$, Iuri Marinov ${ }^{2}$, Robert Petr ${ }^{1}$, \\ Jaroslava Hajkova ${ }^{3}$, Jan Kvasnicka ${ }^{3}$ for the PRAGUE-8 study Investigators
}

\author{
Address: ${ }^{2}$ Third Medical Faculty Charles University \& University Hospital Kralovske Vinohrady, Prague, Czech Republic, ${ }^{2}$ The Institute of \\ Hematology and Blood Transfusion, Prague, Czech Republic and ${ }^{3}$ First Medical Faculty Charles University and Thrombotic Centre General \\ University Hospital, Prague, Czech Republic \\ Email: Zuzana Motovska* - zuzana.motovska@iex.cz; Petr Widimsky - motovskaz@iol.cz; Iuri Marinov - mar@yahoo.com; \\ Robert Petr - Robpe@gmail.com; Jaroslava Hajkova - jarhaj@pobox.sk; Jan Kvasnicka - kvasj@zoznam.sk; the PRAGUE-8 study \\ Investigators - zuzana.motovska@iex.cz \\ * Corresponding author
}

Published: 19 May 2009

Thrombosis Journal 2009, 7:6 doi:10.1 186/1477-9560-7-6
Received: 29 November 2008

Accepted: 19 May 2009

This article is available from: http://www.thrombosisjournal.com/content/7/I/6

(C) 2009 Motovska et al; licensee BioMed Central Ltd.

This is an Open Access article distributed under the terms of the Creative Commons Attribution License (http://creativecommons.org/licenses/by/2.0), which permits unrestricted use, distribution, and reproduction in any medium, provided the original work is properly cited.

\begin{abstract}
Every year, millions of people undergo percutaneous coronary intervention (PCl) with intracoronary stent implantation. A patient from the PRAGUE-8 trial (Optimal pre-PCl clopidogrel loading: $600 \mathrm{mg}$ before every coronary angiography vs. $600 \mathrm{mg}$ in the cath-lab only for PCl patients) is described who suffered from acute stent thrombosis. This patient did not have any relevant inhibition of platelet activation even after the $600 \mathrm{mg}$ dose of clopidogrel. Dose uptitration would have been ineffective. New $\mathrm{P}_{2} \mathrm{Y}_{12}$ receptor inhibitors are desperately needed. In the light of recently published data, the use of prasugrel may be considered as an alternative.
\end{abstract}

\section{Introduction}

Every year, millions of people undergo percutaneous coronary intervention (PCI) with intracoronary stent implantation. Dual antiplatelet therapy - aspirin plus clopidogrel - is recommended for the reduction of acute and subacute stent thrombosis $[1,2]$. Despite combined antiplatelet therapy, stent thrombosis persists at a rate of $0.5-2 \%$ in elective cases, and up to $6 \%$ in patients with acute coronary syndromes [3]. Stent thrombosis is a life-threatening event [4]. In addition, also in cases of immediate reperfusion therapy by means of emergency PCI, patients with stent thrombosis have developed a major myocardial infarction, with consequent significant decline in left ventricular function - a strong negative predictor of long-term survival [3]. "Retrospective" laboratory testing in patients with stent thrombosis has shown that poor response
( "resistance") to antiplatelet therapy is a risk factor for this event [5-7].

\section{Case report}

A 67-year old woman was admitted to Cardiocentre for an elective coronary angiography, because of changes on the ECG (new negative T waves in leads I, aVL, V1-V3) and new anteroapical hypokinesis seen by echocardiography. She was a cigarette smoker, with a history of diabetes, hypertension, hypercholestrolemia on statin therapy (atorvastatin), and with known coronary artery disease on aspirin. The patient fulfilled the inclusion criteria of the PRAGUE-8 trial (see section methods) [8]. After signing of informed consent, she was randomized into group B of this study, and also participated in the vasodilator stimulated phosphoprotein (VASP) phosphorylation state and 
genetic laboratory substudies. In the laboratory substudy, the time course of platelet inhibition after clopidogrel (600 mg loading dose followed by $75 \mathrm{mg}$ per day) was investigated.

On the second day of hospitalization, the patient underwent a coronary angiography, which showed an $80 \%$ stenotic lesion on her left anterior descending artery. The lesion was treated with ad hoc performed PCI with the implantation of a bare metal stent. The success of the procedure was optimal (Figure 1A, B). The next day, the patient was stable, did not have any complications, and was discharged home. The recommendation for drug therapy was as follows: ASA (100 mg/d), clopidogrel $(75 \mathrm{mg} /$ d), metoprolol, ramipril, atorvastatin, peroral antidiabetic.

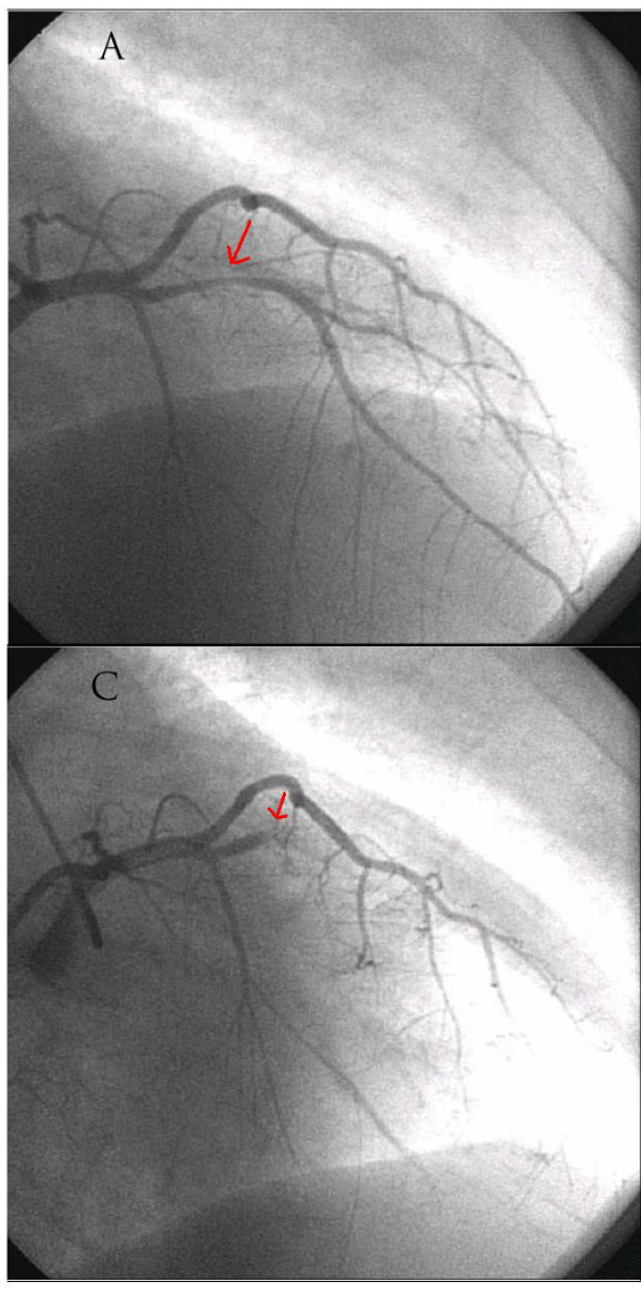

Figure I

Coronary angiography and pecutaneous coronary intevention studies. A, B - elective during the first hospitalization; C, D - urgent during the second hospitlization.

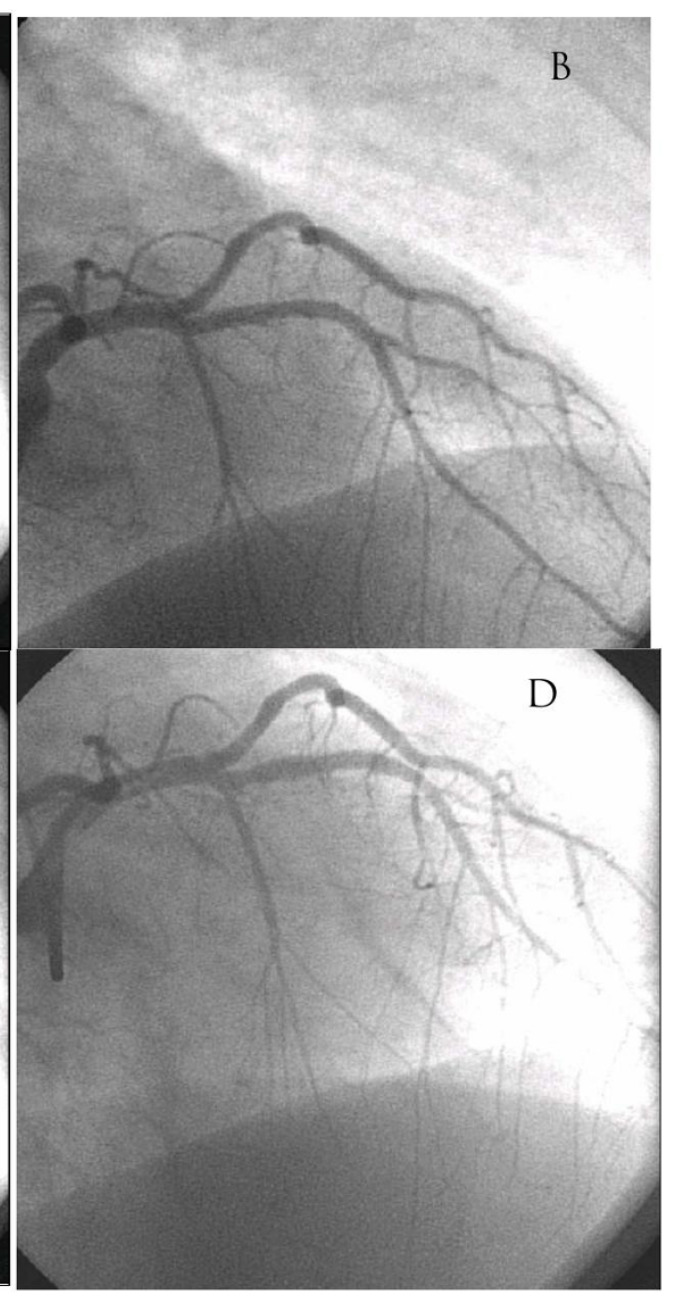

46 hours after stent implantation, the patient returned to the hospital because of chest pain, vertigo and swelling. There were ST segment elevations in leads V1-V3 and a new second-degree A-V block according to the ECG (Figure 2). An emergency coronary angiography was performed, and showed 100\% occlusion of the left anterior descending artery due to acute stent thrombosis. Immediate ballon angioplasty with heparin and eptifibatide opened the artery and led to a good angiographic result (Figure 1C, D).

What did the VASP phosphorylation study show? There was no reaction to the administration of clopidogrel - the patient was completely "resistant" to this drug (Figure 3). Interestingly, by the second admission the ADP-stimulated platelet reactivity was even higher than the basal value without clopidogrel therapy. The most probable 
explanation for this was an acute myocardial infarction, which was the reason for the second hospitalization.

In the genetic substudy we investigated the prevalence of nine platelet and haemostatic gene polymorphisms. The results of this extensive genetic testing are shown in Table 1. Detected single nucleotid polymorphisms of $\mathrm{P}_{2} \mathrm{Y}_{12}$ and GPIIIa receptors had been recognized as possible intrinsic mechanisms of clopidogrel resistance $[8,9]$.

\section{Methods}

The PRAGUE-8 stud $y$ was a randomized multi-center open label clinical trial which compared the routine clopidogrel $600 \mathrm{mg}$ pretreatment more than 6 hours before coronary angiography (group A) with the selective administration of clopidogrel $600 \mathrm{mg}$ only for PCI patients in the catheterization laboratory, after the coronary angiography and just prior to PCI (group B) (ClinicalTrials.gov identifier NCT00432120) [10]. The inclusion criteria were: a planned elective coronary angiography for suspected or proven chronic stable coronary artery disease or medically fully stabilized acute coronary syndrome, a signed written informed consent, and age $\geq 18$ years. The primary end point was the first clinical occurrence of any of the following: death, periprocedural myocardial infarction, stroke or transient ischemic attack, or re-intervention within 7 days. Secondary end-points were: periprocedural troponin elevation (> $3 \times$ ULN), TIMI-flow after PCI, bleeding complications, and each individual component of the combined primary end-point.

Vasodilator Stimulated Phosphoprotein (VASP) is a platelet intracellular actin regulatory protein. The phosphorylation of VASP is regulated by the cyclic adenosine monophosphate cascade. Prostaglandin $\mathrm{E}_{1}$ activates this cascade, whereas it is inhibited by adenosine diphosphate through $\mathrm{P}_{2} \mathrm{Y}_{12}$ receptors. The phosphorylation status of VASP correlates with $\mathrm{P} 2 \mathrm{Y}_{12}$ receptor inhibition, whereas its non-phosphorylation state correlates with the active form of the P2Y $\mathrm{Y}_{12}$ receptor. Levels of VASP phosphorylation/dephosphorylation reflect $\mathrm{P}_{2} \mathrm{Y}_{12}$ inhibition/activation [11]. The effect of thienopyridines can be demonstrated by the persistence of VASP phosphoryla-

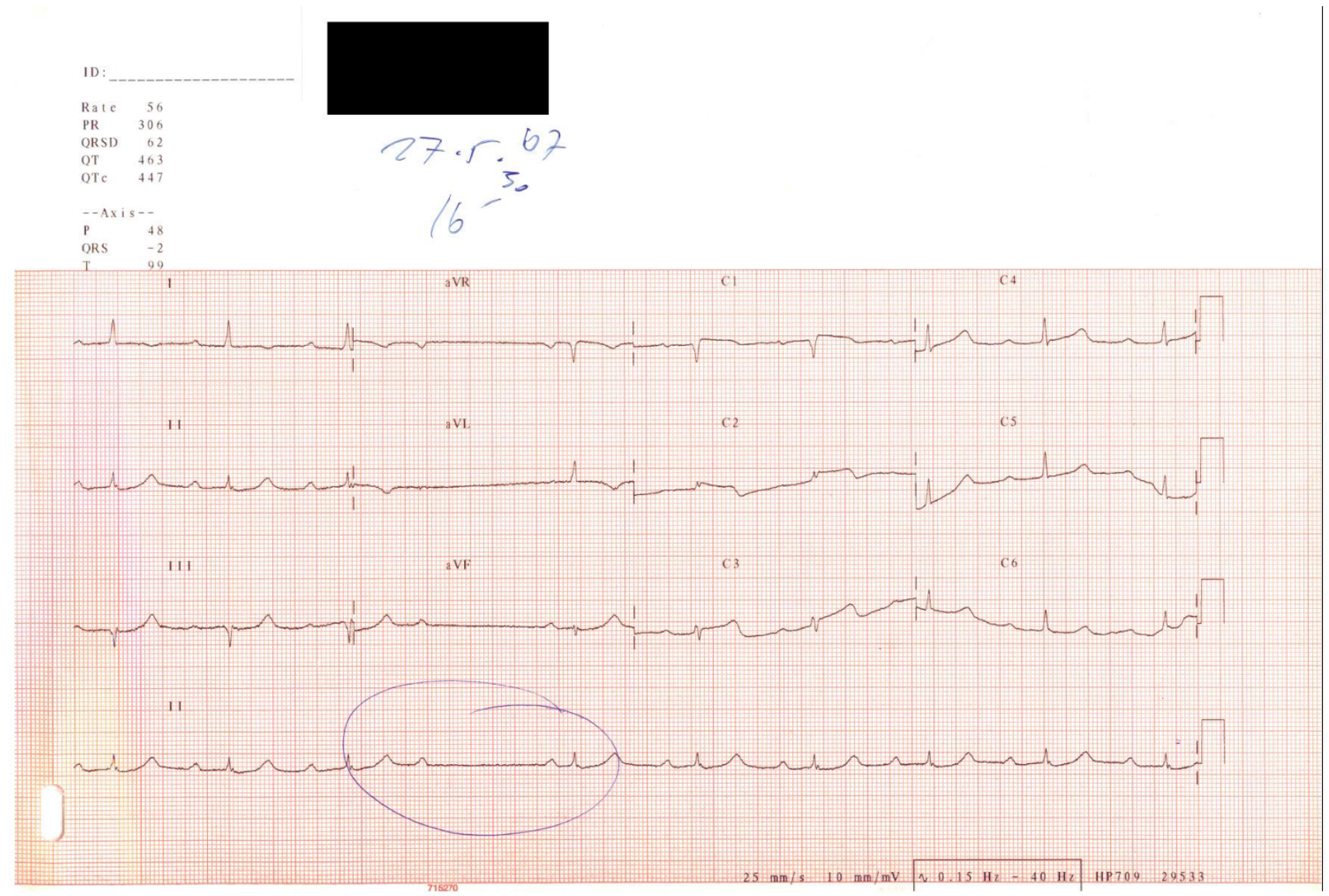

Figure 2

ECG at the second hospital admission. 


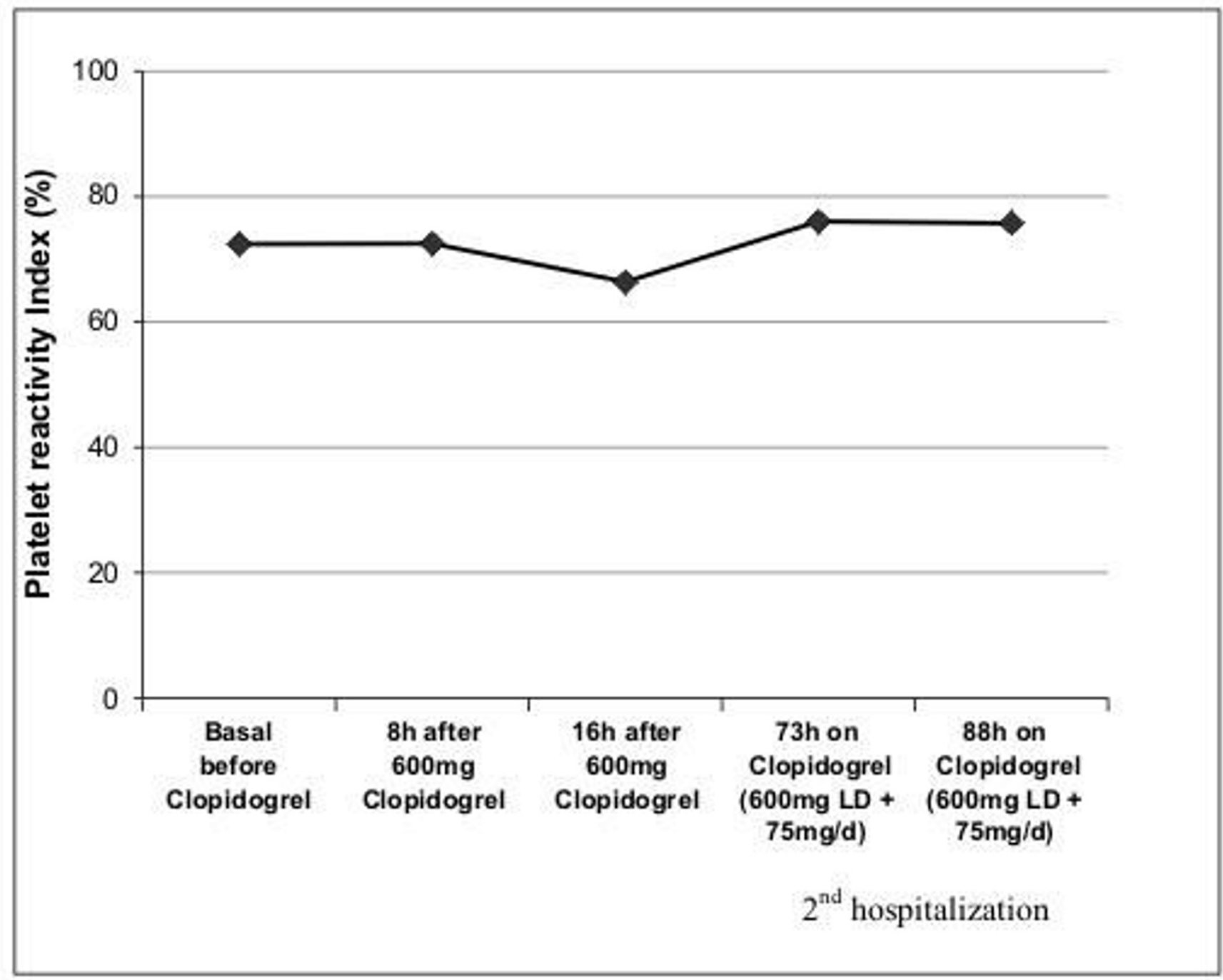

Figure 3

Clopidogrel efficacy; ADP-induced platelet activation (Platelet reactivity index) [I I]before and after clopidogrel.

tion induced by prostaglandin $\mathrm{E}_{1}$, even with the simultaneous addition of ADP $[12,13]$.

Analysis of VASP phosphorylation by flow cytometry. Flow cytometry analysis was done in a laboratory awarded by the Joint Commission International accreditation. Examiners analyzing the VASP phosphorylation state were blinded to the patient-related data. The VASP phosphorylation state was determined in whole blood by flow cytometry using the standardized (CE, IVD) platelet VASP/P2Y 12 assay (Biocytex, France). Briefly, the blood sample was first incubated with prostaglandin $\mathrm{E}_{1}$ alone or prostaglandin $\mathrm{E}_{1}+\mathrm{ADP}$. After cellular permeabilization, VASP under its phosphorylated state was labeled by indirect, no-wash immunofluorescence using a specific mon- oclonal antibody (16C2). Dual-color flow cytometric analysis was performed on a Becton Dickinson FACS Calibur cytometer to compare the two tested conditions, and to evaluate the capacity of ADP to inhibit VASP phosphorylation for each sample. The platelet population was identified by forward scatter, side scatter and fluorescence (anti CD61-PE) gating, then 5000 events were acquired at low rate to list mode files.

A platelet reactivity index (PRI) was calculated from the median fluorescence intensity (MFI) of samples incubated with prostaglandin $\mathrm{E}_{1}$ or prostaglandin $\mathrm{E}_{1}$ and $\mathrm{ADP}$, according to the formula: PRI $=\left[\left(\mathrm{MFI}_{(\mathrm{PGE} 1)}-\right.\right.$ $\left.\mathrm{MFI}_{(\mathrm{PGE} 1+\mathrm{ADP})} / \mathrm{MFI}_{(\mathrm{PGE} 1)}\right] \times 100$. If inhibition of the platelet $\mathrm{P}_{2} \mathrm{Y}_{12}$ receptor by clopidogrel occurs, $\mathrm{ADP}$ fails to cause 
Table I: Genetic testing for platelet polymorphisms and procoagulation state

\begin{tabular}{ll}
\hline Polymorphism & Result \\
\hline Leiden mutation & Negative \\
\hline Factor II mutation & Negative \\
\hline P2YI2 HI/H2 haplotyP & Negative \\
\hline P2YI2 (32C/T) & Heterozygote \\
\hline GPVI (I3254C/T) & Negative \\
\hline PAR-I (IVSn-I4A/T) & Heterozygote \\
\hline GPIIla (PIAI/PIA2) & Heterozygote \\
\hline COX-I (-842A/G) & Negative \\
\hline COX-I (50C/T) & Negative \\
\hline
\end{tabular}

a decrease in VASP phosphorylation and the PRI converges to 0 . In contrast, if treatment is ineffective (i.e. a low responder), dephosphorylation of VASP by ADP still occurs, and the PRI reaches values of $\geq 0.5$ or greater [11].

\section{Discussion}

How should this patient be managed? What do the recommendations say? We have only the expert consensus position regarding aspirin resistance [14]. There is no official expert statement on the problem of clopidogrel ineffectiveness or resistance. The ACC/AHA guidelines recommends that "in patients in whom subacute thrombosis may be catastrophic or lethal, platelet aggregation studies may be considered and the dose of clopidogrel increased to $150 \mathrm{mg}$ per day if less than $50 \%$ inhibition of platelet aggregation is demonstrated" [2].

As Figure 3 shows, our patient did not have any relevant inhibition of ADP-induced platelet reactivity even after the $600 \mathrm{mg}$ clopidogrel. Therefore, dose up-titration would have been ineffective. Administration of GPIIb/IIIa inhibitor during emergency PCI for stent thrombosis has been identified as the only independent predictor for the prevention of recurrent stent thrombosis [3]. Third generation tienopyridine prasugrel provides faster onset and greater inhibition of $\mathrm{P} 2 \mathrm{Y}_{12}$ receptor-mediated platelet aggregation than clopidogrel, because of greater and more efficient generation of the active metabolite $[15,16]$. Pharmacodynamic data have also shown that prasugrel achieves a sufficient degree of platelet inhibition within 30 minutes after treatment [14]. In a crossover study, nonresponders to $300 \mathrm{mg}$ of clopidogrel responded effectively to a loading dose of $60 \mathrm{mg}$ of prasugrel [17]. This favorable laboratory profile resulted in clinical efficacy for prasugrel. The TRITON-TIMI 38 [18] trial recently showed that in comparison to clopidogrel, prasugrel therapy was associated with significantly reduced rates of ischemic events in patients with acute coronary syndromes with scheduled PCI. Stent thrombosis was reduced by approximately $50 \%$ in the prasugrel group compared to the clopidogrel group. The price for this clinical benefit was a significantly higher risk of major bleeding.

In patients with planned elective PCI for whom the optimal time for clopidogrel pretreatment is a day before procedure [19], a test for drug effectiveness before the procedure will identify patients with insufficient platelet inhibition. In these patients, the administration of GPIIb/ IIIa inhibitors during the procedure and a higher dose (150 mg per day) of clopidogrel after stent implantation should be advised to prevent stent thrombosis [2,3]. In patients with no response to the clopidogrel loading dose, prasugrel seems to be an effective alternative [15-18,20]. Flow cytometric determination of VASP phosphorylation state strongly correlated with the inhibition of ADPinduced platelet aggregation resulting from specific $\mathrm{P} 2 \mathrm{Y}_{12}$ blockade by a specific antagonist of the $\mathrm{P} 2 \mathrm{Y}_{12}$ receptor (AR-C69931MX) [6]. This test gives reliable results in whole blood samples kept at room temperature for up to $48 \mathrm{~h}[6,21]$. Aspirin and abciximab did not interfere with VASP phosphorylation $[9,19]$. A flow cytometric analysis of VASP phosphorylation can be recommended as an index (the gold standard) of the efficacy of $\mathrm{P} 2 \mathrm{Y}_{12}$ inhibitors [21].

\section{Conclusion}

In patients with planned elective PCI a flow cytometric VASP phosphorylation test will identify those without sufficient $\mathrm{P}_{2} \mathrm{Y}_{12}$ receptors inhibition and with risk of stent thrombosis. In patients with no response to the clopidogrel loading dose, prasugrel seems to be an effective alternative.

\section{Competing interests}

The authors declare that they have no competing interests.

\section{Authors' contributions}

$\mathrm{ZM}$ was the co-principal investigator of the PRAGUE-8 trial, participated in the design of the study and coordination, drafted the manuscript. PW was the co-principal investigator of the PRAGUE- 8 trial, participated in the design of the study and coordination, participated in critical revision of the manuscript for important intellectual content. IM carried out the flow cytometric analyses. RP carried out the administrative, technical, or material support. JH carried out the molecular genetic studies. JK car- 
ried out the molecular genetic studies. All authors read and approved the final manuscript.

\section{Acknowledgements}

This study was supported by the Charles University Prague Research Project nr. MSM0021620817 and by the Research Project nr.

MZOVFN2005, Ministry of Health, Czech Republic.

\section{References}

I. Silber S, Albertsson P, Aviles FF, Camici PG, Colombo A, Hamm C, Jorgensen E, Marco J, Nordrehaug JE, Ruzyllo W, Urban P, Stone GW, Wijns W: Task Force for Percutaneous Coronary Interventions of the European Society of Cardiology. Guidelines for percutaneous coronary interventions. The Task Force for Percutaneous Coronary Interventions of the European Society of Cardiology. Eur Heart J 2005, 26(8):804-847.

2. Smith SC Jr, Feldman TE, Hirshfeld JW Jr, Jacobs AK, Kern MJ, King SB 3rd, Morrison DA, O'Neil WW, Schaff HV, Whitlow PL, Williams DO, Antman EM, Adams CD, Anderson JL, Faxon DP, Fuster V, Halperin JL, Hiratzka LF, Hunt SA, Nishimura R, Ornato JP, Page RL, Riegel B: American College of Cardiology/American Heart Association Task Force on Practice Guidelines; ACC/AHA/SCAI Writing Committee to Update 200 I Guidelines for Percutaneous Coronary Intervention. ACC/AHA/SCAI 2005 guideline update for percutaneous coronary intervention: a report of the American College of Cardiology/American Heart Association Task Force on Practice Guidelines (ACC/AHA/ SCAI Writing Committee to Update 200 I Guidelines for Percutaneous Coronary Intervention). Circulation 2006, II3(7):el66-286.

3. Wenaweser P, Rey C, Eberli F, Togni M, Tuller D, Locher S, Remondino A, Seiler C, Hess OM, Meier B, Windecker S: Stent thrombosis following bare-metal stent implantation success of emergency percutaneous coronary intervention and predictors of adverse outcome. Eur Heart J 2005, 26( I 2): | | 80- | | 87.

4. Doyle B, Rihal CS, O'Sullivan CJ, Lennon RJ, Wiste HJ, Bell M, Bresnahan J, Holmes DR Jr: Outcomes of stent thrombosis and restenosis during extended follow-up of patients treated with bare-metal coronary stents. Circulation 2007, I I 6(2I):239|-2398

5. Barragan P, Bouvier JL, Roquebert PO, Macaluso G, Commeau P, Comet B, Lafont A, Camoin L, Walter U, Eigenthaler M: Resistance to thienopyridines: clinical detection of coronary stent thrombosis by monitoring of vasodilator-stimulated phosphoprotein phosphorylation. Catheter Cardiovasc Interv 2003, 59(3):295-302.

6. Gurbel PA, Bliden KP, Samara W, Yoho JA, Hayes K, Fissha MZ, Tantry US: Clopidogrel effect on platelet reactivity in patients with stent thrombosis: results of the CREST Study. J Am Coll Cardiol 2005, 46(10): I 827- I832.

7. Wenaweser P, Dörffler-Melly J, Imboden K, Windecker S, Togni M, Meier B, Haeberli A, Hess OM: Stent thrombosis is associated with an impaired response to antiplatelet therapy. J Am Coll Cardiol 2005, 45(I I): I 748-I 752.

8. Nguyen TA, Diodati JG, Pharand C: Resistance to clopidogrel: a review of the evidence. J Am Coll Cardiol 2005, 45(8): I I 57-64.

9. Motovska Z, Widimsky P, Kvasnicka J, Petr R, Bilkova D, Hajkova J, Marinov J, Simek S, Kala P, on behalf of the PRAGUE 8 study investigators: High loading dose of clopidogrel is unable to satisfactorily inhibit platelet reactivity in patients with glycoprotein IIIA gene polymorphism- a genetic substudy of PRAGUE-8 trial. Blood Coagul Fibrinolysis 2009 in press.

10. Widimsky P, Motovska Z, Simek S, Kala P, Pudil R, Holm F, Petr R, Bilkova D, Skalicka H, Kuchynka P, Poloczek M, Miklik M, Maly M, Aschermann M, on behalf of the PRAGUE-8 trial Investigators: Clopidogrel pretreatment in stable angina: for all patients $>6$ hours before elective coronary angiography or only for angiographically selected patients a few minutes before PCI? A randomized multicenter trial PRAGUE-8. Eur Heart J 2008, 29(12): | 495-1503.

II. Aleil B, Ravanat C, Cazenave JP, Rochoux G, Heitz A, Gachet C: Flow cytometric analysis of intraplatelet VASP phosphorylation for the detection of clopidogrel resistance in patients with ischemic cardiovascular diseases. I Thromb Haemost 2005, 3(1):85-92.

12. Schwarz UR, Geiger J, Walter U, Eigenthaler M: Flow cytometry analysis of intracellular VASP phosphorylation for the assessment of activating and inhibitory signal transduction pathways in human platelets-definition and detection of ticlopidine/clopidogrel effects. Thromb Haemost 1999, 82(3): I I 45-II52.

13. Geiger J, Teichmann L, Grossmann R, Aktas B, Steigerwald U, Walter $U$, Schinzel R: Monitoring of clopidogrel action: comparison of methods. Clin Chem 2005, 5 I (6):957-965.

14. Michelson AD, Cattaneo M, Eikelboom JW, Gurbel P, Kottke-Marchant K, Kunicki TJ, Pulcinelli FM, Cerletti C, Rao AK: Aspirin resistance: position paper of the Working Group on Aspirin Resistance. J Thromb Haemost 2005, 3:|309-I3|I.

15. Wallentin L, Varenhorst C, James S, Erlinge D, Braun OO, Jakubowski JA, Sugidachi A, Winters KJ, Siegbahn A: Prasugrel achieves greater and faster P2YI 2receptor-mediated platelet inhibition than clopidogrel due to more efficient generation of its active metabolite in aspirin-treated patients with coronary artery disease. Eur Heart J 2008, 29(1):21-30.

16. Wiviott SD, Trenk D, Frelinger AL, O'Donoghue M, Neumann FJ, Michelson AD, Angiolillo DJ, Hod H, Montalescot G, Miller DL, Jakubowski JA, Cairns R, Murphy SA, McCabe CH, Antman EM, Braunwald E, PRINCIPLE-TIMI 44 Investigators: Prasugrel compared with high loading- and maintenance-dose clopidogrel in patients with planned percutaneous coronary intervention: the Prasugrel in Comparison to Clopidogrel for Inhibition of Platelet Activation and Aggregation-Thrombolysis in Myocardial Infarction 44 trial. Circulation 2007, I I 6(25):2923-2932.

17. Brandt JT, Payne CD, Wiviott SD, Weerakkody G, Farid NA, Small DS, Jakubowski JA, Naganuma H, Winters KJ: A comparison of prasugrel and clopidogrel loading doses on platelet function: magnitude of platelet inhibition is related to active metabolite formation. Am Heart J 2007, 153:66.e9-66.el6.

18. Wiviott SD, Braunwald E, McCabe CH, Montalescot G, Ruzyllo W, Gottlieb S, Neumann FJ, Ardissino D, DeServi S, Murphy SA, Riesmeyer J, Weerakkady G, Gibson CM, Antman EM, TRITON-TIMI 38 Investigators: Prasugrel versus clopidogrel in patients with acute coronary syndromes. N Eng J Med 2007, 357:200I-20I5.

19. Steinhubl SR, Berger PB, Brennan DM, Topol EJ, CREDO Investigators: Optimal timing for the initiation of pre-treatment with $300 \mathrm{mg}$ clopidogrel before percutaneous coronary intervention. J Am Coll Cardiol 2006, 47(5):939-943.

20. Bhatt DL: Intensifying Platelet Inhibition - Navigating between Scylla and Charybdis. New Engl J Med 2007, 357:2078-2081.

21. Gachet C, Aleil B: Testing antiplatelet therapy. Eur Heart J Suppl 2008, I0(suppl A):A28-A34.

Publish with Bio Med Central and every scientist can read your work free of charge

"BioMed Central will be the most significant development for disseminating the results of biomedical research in our lifetime."

Sir Paul Nurse, Cancer Research UK

Your research papers will be:

- available free of charge to the entire biomedical community

- peer reviewed and published immediately upon acceptance

- cited in PubMed and archived on PubMed Central

- yours - you keep the copyright 